\title{
ASSOCIATION OF PARENTAL SOCIOECONOMIC STATUS AND AGE WITH CONSANGUINITY- A SYSTEMATIC REVIEW
}

\author{
Charmode Sundip Hemant ${ }^{1}$
}

${ }^{1}$ Assistant Professor, Department of Anatomy, GMC, Miraj, Sangli, Maharashtra, India. ABSTRACT

\section{BACKGROUND}

Consanguineous marriages are common in India, particularly in southern states and Muslim communities. As far as worldwide scenario is concerned in North and sub-Saharan Africa as well as West, Central and South Asia, around $20 \%$ to $50 \%$ of marriages are consanguineous. Consanguinity is influenced by many socioeconomic factors. Higher rates of consanguinity generally are reported in rural areas, among women who have low education and lower socioeconomic status and with younger age at marriage. Consanguineous unions lead to increased inheritance of autosomal recessive genes, thereby resulting in offspring with congenital defects than compared to non-consanguineous unions. To control the genetic burden of society, it has become increasingly important to spread the awareness regarding this among communities and regions having higher incidence of consanguineous marriages. There is a need to study associated factors like socioeconomic status, age, parity and religion in relation to their influence on incidence of consanguineous unions. Many authors have worked on the same subject and concluded different findings as their studies varied in study location, study population, study design, methodology etc. In this review article, we have done a detailed analysis of old and recent articles addressing the effect of socio-economic status and age on occurrence of consanguineous marriages.

Aim- To assess the association of parental socio-economic status and age with the occurrence of consanguineous unions.

\section{MATERIALS AND METHODS}

An online search was initiated in databases like PubMed, Medline, Cochrane library, Embase, Medline plus, Science Direct, Web of Science, Google Scholar for old and recent articles studying Association of Parental Socioeconomic Status and Age on Consanguinity. Medical terms like consanguinity, congenital defects, socioeconomic status, parental age etc. were used to search the articles. Around 22 articles were found since 1958 till date. Amongst 22 articles, fifteen articles having significant conclusions were shortlisted and their results were analysed, compared with other articles and also with the author's own study. ${ }^{1}$ The shortlisting was done by going through the abstract/ full article of all the articles.

Study Settings and Design- ESIC Medical College and Hospital, Gulbarga, Systematic Review article.

\section{RESULTS}

Almost all studies have concluded that incidence of consanguineous marriage is more common in lower socio-economic class. Lower the age of female or male, more is the possibility of them to undergo consanguineous union. These observations are consistent in studies conducted in various regions of the world and amongst various communities, although the incidence varies. Observations regarding association of maternal age and socio-economic status with consanguinity were statistically significant more often than those regarding association of paternal age and socio-economic status with consanguinity. Hence, female education needs to be encouraged followed by strong measures ensuring her socio-economic stability. Awareness regarding harmful genetic effects of consanguineous unions should be spread profusely amongst highly prevalent regions and communities.

\section{CONCLUSION}

1. Increased incidence of consanguineous unions is observed amongst parents of lower socio-economic status.

2. Increased incidence of consanguineous unions is observed amongst couples marrying at a younger age.

3. Consanguineous unions result in increased incidence of premature births, perinatal mortality and congenitally anomalous offspring.

4. Consanguineous unions results in increased incidence of low birth weight offspring and those with lower anthropometric values.

\section{KEY WORDS}

Consanguinity, Congenital Defects, Socioeconomic Status, Parental Age, Parental Education, Consanguineous Marriages.

HOW TO CITE THIS ARTICLE: Hemant CS. Association of parental socioeconomic status and age with consanguinity- a systematic review. J. Evolution Med. Dent. Sci. 2018;7(34):3799-3803, DOI: 10.14260/jemds/2018/852

'Financial or Other Competing Interest': None.

Submission 04-07-2018, Peer Review 03-08-2018,

Acceptance 09-08-2018, Published 20-08-2018.

Corresponding Author:

Charmode Sundip Hemant,

Assistant Professor, Department of Anatomy,

GMC, Miraj, Sangli,

Maharashtra, India.

E-mail: sundip.charmode@yahoo.com

DOI: $10.14260 /$ jemds $/ 2018 / 852$

(c) (i) $\ominus$

\section{BACKGROUND}

Consanguineous marriages are common in India, particularly in southern states, Muslim communities and few communities in North India. As far as worldwide scenario is concerned in North and sub-Saharan Africa as well as West, Central and South Asia, around $20 \%$ to $50 \%$ of marriages are consanguineous. $^{2}$ In the Middle East, the incidence of consanguineous unions varies between $21 \%$ in Lebanon and $58 \%$ in Saudi Arabia. ${ }^{3}$

Consanguinity is influenced by many socioeconomic factors. Higher rates of consanguinity generally are reported 
in rural areas, among women who have low education and lower socioeconomic status and with younger age at marriage. $^{3-8}$ PS Rao and SG Inbaraj $^{9}$ in 1980 stated contrasting conclusions from their study. Consanguineous unions lead to occurrence of congenitally anomalous offsprings compared to non-consanguineous union is well accepted all over the world. Hence, to control the genetic burden of society, it has become increasingly important to spread the awareness regarding this among communities and regions having higher incidence of consanguineous marriages.

There is a need to study associated factors like socioeconomic status, age, parity and religion in relation to their influence on incidence of consanguineous unions. Many authors have worked on the same subject and concluded different findings as their studies varied in study location, study population, study design and methodology. In this review article, we have done a detailed analysis of old and recent articles addressing the effect of socio-economic status and age on occurrence of consanguineous marriages.

\section{MATERIALS AND METHODS}

An online search was initiated in databases like PubMed, Medline, Cochrane library, Embase, Medline plus, Science Direct, Web of Science, Google Scholar for old and recent articles studying Association of Parental Socioeconomic Status and Age on Consanguinity. Medical terms like consanguinity, congenital defects, socioeconomic status, parental age etc. were used to search the articles. Around 22 articles were found since 1958 till date. Amongst 22 articles, fifteen articles having significant conclusions were shortlisted and their results were analysed, compared with other articles and also with the author's own study. ${ }^{1}$ The shortlisting was done by going through the abstract/ full article of all the articles.

\begin{tabular}{|c|c|c|c|}
\hline Sl. No. & Author & Title of Study & Database \\
\hline 1 & William Schull10 1958 & $\begin{array}{l}\text { Empirical Risks in consanguineous marriages: Sex ratio, Malformation } \\
\text { and viability }\end{array}$ & \\
\hline 2 & M Anthony Schork ${ }^{11} 1964$ & The Effects of Inbreeding on Growth & \\
\hline 3 & P S Rao, S G Inbaraj9 1980 & Inbreeding effects on foetal growth and development & \\
\hline 4 & $\begin{array}{l}\text { ML Kulkarni, MA Mathew, V Reddy }{ }^{12} \\
1990\end{array}$ & $\begin{array}{c}\text { Consanguinity and its effect on foetal growth and development- a South } \\
\text { Indian study }\end{array}$ & \\
\hline 5 & $\begin{array}{l}\text { Sarah Bundey, Hasina Alam et } \text { al }^{13} \text { in } \\
1990\end{array}$ & $\begin{array}{l}\text { Race, consanguinity and social features in Birmingham babies: a basis } \\
\text { for prospective study }\end{array}$ & \\
\hline 6 & Khlat and Khoury 1991 & $\begin{array}{c}\text { Inbreeding and Diseases: Demographic, Genetic and Epidemiologic } \\
\text { perspectives }\end{array}$ & PubMed \\
\hline 7 & AH Bittles, WM Mason et al 1991 & Reproductive behaviour and health in consanguineous marriages & \\
\hline 8 & Bittles AH, Grant JC et al6 1993 & $\begin{array}{l}\text { Consanguinity as a determinant of reproductive behaviour and } \\
\text { mortality in Pakistan }\end{array}$ & \\
\hline 9 & Mohamed MS7 1995 & $\begin{array}{l}\text { An epidemiological study on consanguineous marriage among } \\
\text { urban population in Alexandria }\end{array}$ & \\
\hline 10 & $\begin{array}{l}\text { Abdul Wahab, Mahumud Ahmad14 } \\
1996\end{array}$ & $\begin{array}{l}\text { Biosocial perspective of consanguineous marriages in rural and urban } \\
\text { Swat, Pakistan }\end{array}$ & \\
\hline 11 & $\begin{array}{l}\text { Camilla Stoltenberg, Per Magnus }{ }^{8} \\
1997\end{array}$ & Birth defects and Parental consanguinity in Norway & \\
\hline 12 & Al Hussain M, Al Bunyan M15 1997 & $\begin{array}{c}\text { Consanguineous marriages in a Saudi population and the effect } \\
\text { of inbreeding on prenatal and postnatal mortality }\end{array}$ & \\
\hline 13 & Hussain R, Bittles AH 162000 & $\begin{array}{l}\text { Socio-demographic correlates of consanguineous marriage in the } \\
\text { Muslim population of India }\end{array}$ & \\
\hline 14 & Bittles $\mathrm{AH}^{17} 2002$ & Endogamy, Consanguinity and Community genetics & \\
\hline 15 & Hussain R, Bittles AH ${ }^{18} 2004$ & $\begin{array}{l}\text { Assessment of association between consanguinity and fertility in Asian } \\
\text { populations }\end{array}$ & \\
\hline 16 & $\begin{array}{l}\text { Abdul Wahab, Mahumud Ahmad }{ }^{19} \\
2005\end{array}$ & $\begin{array}{l}\text { Consanguineous Marriages in the Sikh Community of Swat, } \\
\text { NWFP, Pakistan }\end{array}$ & \\
\hline 17 & Kerkeni E, Monastiri20 2006 & $\begin{array}{l}\text { Association among education level, occupational status and } \\
\text { consanguinity in Tunisia and Croatia }\end{array}$ & \\
\hline 18 & A Bener, R Hussain 2006 & Consanguineous unions and child health in the state of Qatar & \\
\hline 19 & Khalid Yunis, Reem El Rafei21 2008 & $\begin{array}{l}\text { Consanguinity: Perinatal Outcomes and Prevention- A view from the } \\
\text { Middle East }\end{array}$ & \\
\hline 20 & Harlap S, Kleinhaus K22 2008 & Consanguinity and birth defects in the Jerusalem perinatal study cohort & \\
\hline 21 & M Ture, B Tugrul et al 232009 & Consanguineous marriages in Denizli, Turkey & \\
\hline 22 & Jurdi R, Saxena P C24 2003 & $\begin{array}{l}\text { The prevalence and correlates of Consanguineous marriages in Yemen: } \\
\text { similarities and contrasts with other Arab countries }\end{array}$ & PubMed \\
\hline
\end{tabular}




\begin{tabular}{|c|c|c|c|c|c|c|c|c|}
\hline $\begin{array}{l}\text { Sl. } \\
\text { No. }\end{array}$ & Authors & $\begin{array}{c}\text { Type } \\
\text { of } \\
\text { Study }\end{array}$ & $\begin{array}{c}\text { Consanguinity and } \\
\text { Maternal } \\
\text { Education }\end{array}$ & $\begin{array}{c}\text { Consanguinity } \\
\text { and Paternal } \\
\text { Education }\end{array}$ & \begin{tabular}{|c|} 
Consanguinity \\
and Maternal \\
Occupation
\end{tabular} & $\begin{array}{l}\text { Consanguinity } \\
\text { and Paternal } \\
\text { Occupation }\end{array}$ & $\begin{array}{c}\text { Consanguinity } \\
\text { and Maternal } \\
\text { Age }\end{array}$ & $\begin{array}{c}\text { Consanguinity } \\
\text { and Paternal } \\
\text { Age }\end{array}$ \\
\hline 1 & $\begin{array}{c}\text { William Scull10 } \\
1958\end{array}$ & & 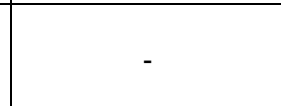 & 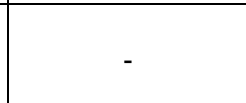 & 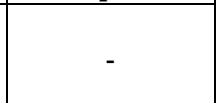 & 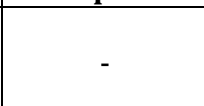 & $\begin{array}{l}\text { Inverse } \\
\text { correlation }\end{array}$ & 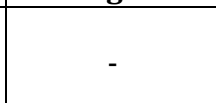 \\
\hline 2 & $\begin{array}{c}\text { PS Rao et al }^{9} \\
1980\end{array}$ & & $\begin{array}{c}\text { No significant } \\
\text { difference }\end{array}$ & $\begin{array}{c}\text { No significant } \\
\text { difference }\end{array}$ & $\begin{array}{c}\text { No significant } \\
\text { difference }\end{array}$ & $\begin{array}{c}\text { No significant } \\
\text { difference }\end{array}$ & $\begin{array}{c}\text { No significant } \\
\text { difference }\end{array}$ & $\begin{array}{c}\text { No significant } \\
\text { difference }\end{array}$ \\
\hline 3 & \begin{tabular}{|l} 
ML Kulkarni, MA \\
Mathew, V \\
Reddy 121989 \\
\end{tabular} & & (n) & - & - & - & Not studied & ( \\
\hline 4 & $\begin{array}{c}\text { Khlat and } \\
\text { Khoury4 } 1991\end{array}$ & & Not studied & - & Not studied & - & Not studied & - \\
\hline 5 & $\begin{array}{l}\text { Mohamed MS } \\
\text { Study } 1995 \\
\end{array}$ & & - & - & - & - & $\begin{array}{l}\text { Negative } \\
\text { correlation }\end{array}$ & $\begin{array}{c}\text { Negative } \\
\text { correlation }\end{array}$ \\
\hline 6 & $\begin{array}{c}\text { Al Husain M, al } \\
\text { Bunyan M15 } \\
1997 \\
\end{array}$ & & - & - & - & - & $\begin{array}{l}\text { Inverse } \\
\text { association }\end{array}$ & $\begin{array}{l}\text { Inverse } \\
\text { association }\end{array}$ \\
\hline 7 & $\begin{array}{c}\text { Bittles } \mathrm{AH}^{17} \\
2002 \\
\end{array}$ & & Inverse correlation & - & $\begin{array}{c}\text { Inverse } \\
\text { correlation }\end{array}$ & - & - & - \\
\hline 8 & $\begin{array}{c}\text { Jurdi R, Saxena P } \\
\mathrm{C}^{24} 2003\end{array}$ & & Inverse correlation & Direct correlation & $\begin{array}{c}\text { Inverse } \\
\text { correlation }\end{array}$ & $\begin{array}{c}\text { Direct } \\
\text { correlation }\end{array}$ & $\begin{array}{c}\text { Inverse } \\
\text { correlation }\end{array}$ & - \\
\hline 9 & $\begin{array}{c}\text { Hussain R, } \\
\text { Bittles AH }{ }^{18} \\
2004\end{array}$ & & Inverse correlation & - & 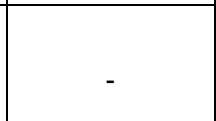 & - & $\begin{array}{l}\text { Inverse } \\
\text { correlation }\end{array}$ & - \\
\hline 10 & $\begin{array}{c}\text { Abdul Wahab } \\
\text { and Mahmud } \\
\text { Ahmad }^{19} 2005\end{array}$ & & Inverse correlation & $\begin{array}{l}\text { Inverse } \\
\text { correlation }\end{array}$ & $\begin{array}{l}\text { Inverse } \\
\text { correlation }\end{array}$ & $\begin{array}{l}\text { Inverse } \\
\text { correlation }\end{array}$ & Not specified & Not specified \\
\hline 11 & $\begin{array}{c}\text { AH Bittles, WM } \\
\text { Mason et al }{ }^{5} \\
1991\end{array}$ & & - & - & - & - & $\begin{array}{l}\text { Inverse } \\
\text { correlation }\end{array}$ & $\begin{array}{l}\text { Inverse } \\
\text { correlation }\end{array}$ \\
\hline 12 & $\begin{array}{c}\text { Kerkeni E, } \\
\text { Monastiri20 } 2006\end{array}$ & & $\begin{array}{l}\text { Significant inverse } \\
\text { correlation }\end{array}$ & $\begin{array}{c}\text { Insignificant } \\
\text { inverse } \\
\text { correlation } \\
\end{array}$ & $\begin{array}{c}\text { Significant } \\
\text { inverse } \\
\text { correlation } \\
\end{array}$ & $\begin{array}{c}\text { Insignificant } \\
\text { inverse } \\
\text { correlation } \\
\end{array}$ & - & - \\
\hline 13 & $\begin{array}{c}\text { Harlap S, } \\
\text { Kleinhaus K²2 } \\
2008 \\
\end{array}$ & & $\begin{array}{l}\text { Significant inverse } \\
\text { correlation }\end{array}$ & $\begin{array}{c}\text { Significant } \\
\text { inverse } \\
\text { correlation }\end{array}$ & $\begin{array}{l}\text { Significant } \\
\text { inverse } \\
\text { correlation } \\
\end{array}$ & $\begin{array}{l}\text { Significant } \\
\text { inverse } \\
\text { correlation }\end{array}$ & $\begin{array}{l}\text { Significant } \\
\text { inverse } \\
\text { correlation } \\
\end{array}$ & $\begin{array}{l}\text { Significant } \\
\text { inverse } \\
\text { correlation } \\
\end{array}$ \\
\hline 14 & $\begin{array}{c}\text { Khalid Yunis, } \\
\text { Reem El Rafei } 21 \\
2008 \\
\end{array}$ & & Inverse correlation & $\begin{array}{l}\text { Inverse } \\
\text { correlation }\end{array}$ & $\begin{array}{l}\text { Inverse } \\
\text { correlation }\end{array}$ & $\begin{array}{l}\text { Inverse } \\
\text { correlation }\end{array}$ & $\begin{array}{l}\text { Inverse } \\
\text { correlation }\end{array}$ & $\begin{array}{l}\text { Inverse } \\
\text { correlation }\end{array}$ \\
\hline 15 & $\begin{array}{c}\text { M. Ture, B } \\
\text { Tugrul et al }{ }^{23} \\
2009\end{array}$ & & $\begin{array}{c}\text { Negative } \\
\text { association }\end{array}$ & $\begin{array}{l}\text { Negative } \\
\text { association }\end{array}$ & Not specified & Not specified & $\begin{array}{c}\text { Negative } \\
\text { association }\end{array}$ & $\begin{array}{l}\text { Negative } \\
\text { association }\end{array}$ \\
\hline
\end{tabular}

\section{DISCUSSION}

\section{Consanguinity and Parental Socio-Economic Status}

Kerkeni E, Monastiri 20 in 2006 stated that however our study showed the negative association of education level and occupation status with consanguineous marriages is mainly seen among women, but not in men.

Harlap S and Kleinhaus $\mathrm{K}^{22}$ in 2008 concluded consanguinity to be strongly related to lower education, lower occupational social class and childbearing by parents at the extremes of age, as has been shown in other settings.

Khalid Yunis and Reem El Rafei ${ }^{21}$ in 2008 reviewed in his article that consanguinity is more prevalent in Muslim communities. It is linked more to cultural and historical factors than to religious ones. ${ }^{25,26}$ Consanguinity is influenced by many socioeconomic factors. Higher rates generally are reported in rural areas, among women who have low education and socioeconomic status and with younger age at marriage. ${ }^{2,3}$

Abdul Wahab and Mahmud Ahmad ${ }^{19}$ in 2005 studied marriages among the Sikh minority of the Districts of Swat, Bunair and Shangla (NWFP, Pakistan) and concluded that the inbreeding coefficient for the population was 0.0127. Mean inbreeding coefficient was higher for the low socioeconomic group (0.0181) and lower for the high socioeconomic group (0.0125). An increase in the incidence of consanguineous marriages over the years has been observed.

Hussain $\mathrm{R}$ and Bittles $\mathrm{AH}^{18}$ in 2004 studied the association between consanguinity and fertility by reviewing published literature and analysing Demographic and Health Survey (DHS) data from Pakistan and India. They found consanguinity to be associated with a number of direct and indirect determinants of fertility including lower maternal education, lower maternal age at marriage, lower contraceptive use and rural residence. 
Jurdi R and Saxena PC24 in 2003 using data on 9762 women from the 1997 Yemen Demographic and Maternal and Child Health Survey, examined the prevalence and socioeconomic correlates of consanguineous marriages in Yemen. Their study confirmed the inverse association between consanguineous marriages and women's education and occupation, age at marriage and economic status. However, no statistically significant difference in the prevalence of consanguinity has been found by place of residence and geographical region.

Bittles $\mathrm{AH}^{17} 2002$ stated that the highest rates of consanguineous marriage in South India were usually reported in traditional rural areas and among the poorest and least educated groups.

M Ture and B Tugrul et al23 interviewed 1000 families during 1996 in the city of Denizli, and observed the overall rate of consanguinity to be $11.7 \%$ with a mean inbreeding coefficient of 0.00873 . The principal type of consanguineous marriage recorded was between first cousins, which accounted for $49.6 \%$ of all unions. For both sexes, a significant negative association was observed between consanguinity and mean age at marriage and level of education.

\section{Consanguinity and Parental Age}

William Scull 10 in 1958 stated that consanguineous marriages do differ significantly from non-consanguineous marriages with regard to (1) Maternal age, (2) Parity, (3) Paternal age and (4) The frequency of "therapeutic" interruption of pregnancies.

Mohamed MS7 study in 1995 concluded that age at marriage was younger in consanguineous marriages than non-consanguineous marriages.

Al Husain M and Al Bunyan M15 in 1997 stated that there was a significant association between the level of education and consanguinity.

AH Bittles, WM Mason et al ${ }^{5}$ in 1991 stated in their study that consanguinity is associated with increased gross fertility, due at least in part to younger maternal age at first live birth. Whereas, few authors in their studies stated contradictory findings/ conclusions.

For e.g. PS Rao et $\mathrm{al}^{9}$ in 1980 in their study carried out in rural and urban areas of North Arcot District in Tamilnadu State in South India concluded that no significant differences existed in the incidence of congenital anomalies among offspring between the consanguineous and nonconsanguineous marriages in the rural or in the urban area. Neither were any significant trends seen by degree of consanguinity or by birth order, or by the different age groups. The types of malformations and their frequency seen in the consanguineous and non-consanguineous groups were similar. There were also no significant differences observed by type of marriage in both areas in gestational age, birth weight, body length, head circumference or chest circumference.

ML Kulkarni, MA Mathew, V Reddy ${ }^{12}$ in 1989 in their study amongst 3700 births found that consanguineous unions were found to occur in $24 \%$ of total lower income group; whereas amongst middle/ upper income group, it was found in $28.9 \%$. This conclusion contradicts the general conclusion done by almost all studies done all over the world that consanguineous unions are more common in lower socioeconomic strata of society.

Khlat and Khoury 4 in 1991 stated that prevalence of consanguineous unions is highest in Arab countries followed by India, Japan, Brazil and Israel. They are most common in lower educational and socioeconomic groups, the traditionally religious and the early married, but are declining with modernisation.

Author's own article $^{1}$ states that consanguineous marriages and offsprings with congenital defect are observed to occur more commonly to parents of low socio-economic and lower educational status. So, we can state that conclusions obtained in our study matches with that of majority of studies done in different communities and different geographical regions of the world.

\section{CONCLUSION}

1. Increased incidence of consanguineous unions is observed amongst parents of lower socio-economic status.

2. Increased incidence of consanguineous unions is observed amongst couples marrying at a younger age.

3. Consanguineous unions result in increased incidence of prematurity, perinatal mortality and congenital anomalous offspring.

4. Consanguineous unions result in increased incidence of low birth weight offspring and those with lower anthropometric values.

\section{REFERENCES}

[1] Charmode SH. Association of educational, occupational status and religion with consanguinity. Journal of Evolution of Medical and Dental Sciences 2016;5(34):1939-1945.

[2] Bittles AH. Consanguinity and its relevance to clinical genetics. Clin Genet 2001;60(2):89-98.

[3] Bener A, Hussain R. Consanguineous unions and child health in the state of Qatar. Paediatr Perinat Epidemiol 2006;20(5):372-8.

[4] Khlat M, Khoury M. Inbreeding and diseases: demographic, genetic, and epidemiologic perspectives. Epidemiol Rev 1991;13:28-41.

[5] Bittles AH, Mason WM, Greene J, et al. Reproductive behavior and health in consanguineous marriages. Science 1991;252(5007):789-94.

[6] Bittles AH, Grant JC, Shami SA. Consanguinity as a determinant of reproductive behaviour and mortality in Pakistan. Int J Epidemiol 1993;22(3):463-7.

[7] Mohamed MS. An Epidemiological study on consanguineous marriage among urban population in Alexandria. J Egypt Public Health Assoc 1995;70(34):293-305.

[8] Stoltenberg C, Magnus P, Lie RT, et al. Birth defects and parental consanguinity in Norway. Am J Epidemiol 1997;145(5):439-48.

[9] Rao PS, Inbaraj SG. Inbreeding effects on fetal growth and development. J Med Genet 1980;17(1):27-33.

[10] Schull WJ. Empirical risks in consanguineous marriages: sex ratio, malformation and viability. Am J Hum Genet 1958;10(3):294-343.

[11] Schork MA. The effects of inbreeding on growth. Am J Hum Genet 1964;16(3):292-300. 
[12] Kulkarni ML, Kurian M. Consanguinity and its effect on fetal growth and development: a south Indian study. J Med Genet 1990;27(6):348-52.

[13] Bundey S, Alam H, Kaur A, et al. Race, consanguinity and social features in Birmingham babies: a basis for prospective study. J Epidemiol Community Health 1990;44(2):130-5.

[14] Wahab A, Ahmad M. Biosocial perspective of consanguineous marriages in rural and urban swat, Pakistan. J Biosoc Sci 1996;28(3):305-13.

[15] al Husain M, al Bunyan M. Consanguineous marriages in a Saudi population and the effect of inbreeding on prenatal and postnatal mortality. Ann Trop Paediatr 1997;17(2):155-60.

[16] Hussain R, Bittles AH. Socio-demographic correlates of consanguineous marriage in the Muslim population of India J Biosoc Sci 2000;32(4):433-42.

[17] Bittles AH. Endogamy, consanguinity and community genetics. J Genet 2002;81(3):91-8.

[18] Hussain R, Bittles AH. Assessment of association between consanguinity and fertility in Asian populations. J Health Popul Nutr 2004;22(1):1-12.
[19] Wahab A, Ahmad M. Consanguineous Marriages in the Sikh community of Swat, NWFP, Pakistan. J Soc Sci 2005;10(3):153-7.

[20] Kerkeni E, Monastiri K, Saket B, et al. Association among education level, occupation status, and consanguinity in Tunisia and Croatia. Croat Med J 2006;47(4):656-61.

[21] Yunis K, El Rafei R, Mumtaz G. Consanguinity: perinatal outcomes and prevention - a view from the middle-east. Neo-Reviews 2008;9(2):59-64.

[22] Harlap S, Kleinhaus K, Perrin MC, et al. Consanguinity and birth defects in the Jerusalem perinatal study cohort. Hum Hered 2008;66(3):180-9.

[23] Simşek S, Türe $M$, Tugrul $B$, et al. Consanguineous marriages in Denizli, Turkey. Ann Hum Biol 1999;26(5):489-91.

[24] Jurdi R, Saxena PC. The prevalence and correlates of consanguineous marriages in Yemen: similarities and contrasts with other Arab countries. J Biosoc Sci 2003;35(1):1-13. 